\title{
PERLINDUNGAN HUKUM TERHADAP KONSUMEN PARKIR
}

\author{
Basri \\ Fakultas Hukum Universitas Borneo Tarakan \\ e-mail: basriubt@gmail.com
}

\begin{abstract}
ABSTRAK
Perilaku dan kehidupan masyarakat selalu dinamis sesuai dengan kebutuhan hidup sebagai sarana penunjang dalam melakukan aktifitas keseharian. Karena faktor pelayanan publik yang berkaitan dengan angkutan umum tidak jelas akan rute dan trayeknya, maka mayoritas masyarakat lebih memanfaatkan kendaraan pribadi, keadaan ini selaras dengan intensitas penjualan kendaraan. Tempat parkir kendaraan bermotor menjadi kebutuhan bagi pemilik kendaraan, karenanya parkir harus mendapat perhatian yang serius, terutama mengenai pengaturannya. Salah satu hal yang penting dalam pengelolaan parkir adalah mengenai masalah perlindungan bagi konsumen pengguna jasa parkir mengenai keamanan kendaraan yang diparkir di tempat parkir. Pengguna jasa parkir tentunya tidak menginginkan kendaraan yang diparkir mengalami kerusakan atau kehilangan kendaraan yang diparkir. Namun tentu saja kemungkinan tersebut sering terjadi, sehubungan dengan hal tersebut maka timbullah pertanyaan, siapa yang bertanggungjawab terhadap kehilangan atau kerusakan kendaraan bermotor yang di parkir di tempat parkir.
\end{abstract}

Kata Kunci: hukum, perlindungan, konsumen.

\begin{abstract}
People's lives and behavior are always dynamic in accordance with the necessities of life as a supportive media in performing daily activities. Because of public services related to public transport is unclear and unsure, major people take better advantage of private vehicles, where the fact is the state is in line with the intensity of vehicle sales. Motorbike vehicle parking space is needed, hence the parking should receive serious attention. One thing that is important in the management of the parking is on the issue of protection of parking service consumer that parked in the parking lot. Parking service users certainly do not want a parked vehicle got damaged or lost. But of course the possibility that often occur in connection with the matter, the question arises, who is responsible for the lost or damage to motor vehicles parked in the parking lot.
\end{abstract}

Keywords: law, protection, consumer.

\section{PENDAHULUAN}

Pertumbuhan perekonomian dan perkembangan jumlah kendaraan bermotor sangat pesat saat ini namun tidak diimbangi dengan perkembangan dan perbaikan terhadap infrastruktur baik sarana maupun prasarana, sehingga terjadi ketidakseimbangan. Selanjutnya, ini menjadi salah satu indikator penyebab terjadinya berbagai berbagai macam masalah transportasi misalnya kemacetan-kemacetan dan kebutuhan akan fasilitas parkir bagi kendaraan akan terus meningkat sejalan dengan meningkatnya jumlah kendaraan yang ada dimasyarakat umum baik itu wilayah perkotaan maupun perdesaan yang menimbulkan keresahan terhadap ketersediaan wilayah parkir. ${ }^{1}$

Sebagai contoh dalam penelitian ini penulis mengkaji Kota Tarakan sebagai objek penelitian. Tarakan berdasarkan rekap data bulanan Samsat Tarakan (kendaraan masuk-keluar dan penunaian

${ }^{1}$ Perkembangan Jumlah Kendaraan Bermotor Menurut Jenis Tahun 1987-2011, http://wwwbps.go.id/tab_sub/view. php?tabel $=1 \&$ daftar $=1 \&$ id_subyek $=17 \&$ notab $=12$, diakses tgl 08 Maret 2013. 
kewajiban pajak kendaraan) per 31 Agustus 2013; kendaraan baru yang masuk ke Tarakan, totalnya sebanyak 767 unit kendaraan dengan rincian sedang 0 unit, jeep 0 unit, mini bus 22 unit, bus/micro 0 unit, pikap 22 unit, light truck 0 unit, truck 7 unit, alat berat 0 unit, dan sepeda motor 725 unit. $^{2}$ Dan, akumulasi jumlah kendaraan berdasarkan jenisnya hingga tanggal 31 Agustus lalu; sedan 405 unit, jeep 820 unit, mini bus 5.879 unit, bus/micro 49 unit, pikap 2.452 unit, light truck 110 unit, truck 1224 unit, alat berat 285 unit, sepeda motor 85.773 unit, atau total kendaraan yang ada di Tarakan hingga bulan Agustus lalu sebanyak 96.997 unit kendaraan. ${ }^{3}$

Tempat parkir kendaraan bermotor menjadi kebutuhan bagi pemilik kendaraan karenanya, parkir harus mendapat perhatian yang serius, terutama mengenai pengaturannya. Salah satu hal yang penting dalam pengelolaan parkir adalah mengenai masalah perlindungan bagi konsumen pengguna jasa parkir mengenai keamanan kendaraan yang di parkir di tempat parkir. Pengguna jasa parkir tentunya tidak menginginkan kendaraan yang diparkir mengalami kerusakan atau kehilangan kendaraan yang diparkir. Namun tentu saja kemungkinan tersebut sering terjadi sehubungan dengan hal tersebut maka timbullah pertanyaan, siapa yang bertanggungjawab terhadap kehilangan atau kerusakan kendaraan bermotor yang di parkir di tempat parkir. Lalu bagaimana implementasi perlindungan konsumen jasa parkir di kota Tarakan, terkait dengan hak konsumen dan kewajiban pihak pengelola parkir.

Peneliti menfokuskan pada tempat-tempat parkir umum yang ada di kota Tarakan seperti apa pelaksanaan parkir yang dilakukan oleh pihakpihak pengelola jasa parkir diantaranya lokasi yang diteliti ialah pengelolaan parkir di Bandara Juwata Tarakan, Pengelolaan parkir di Grand Tarakan Mall, Pengelolaan parkir di Gusher Plasa, pengelolaan parkir di THM Plaza dan parkir-parkir pinggir jalan.

Pengelolaan parkir di Bandara Juwata Tarakan, setiap pemilik kendaraan yang akan masuk di wilayah Bandara Juwata Tarakan di pintu masuk akan mengambil karcis parkir dari mesin otomatis yang akan mengeluarkan karcis parkir dan pada saat keluar maka karcis parkir tersebut diserahkan dan akan diperiksa oleh petugas loket di pintu keluar

\footnotetext{
${ }^{2}$ Kantor Kepolisian Republik Indonesia sejak 1999 tidak termasuk Timor-Timur.

${ }^{3}$ Kaltara Raya, Radar Tarakan, 20 September 2013.
}

parkir bandara sekaligus membayar ongkos parkir sesuai dengan tarif yang sudah ditentukan.

Pengelolaan parkir di Grand Tarakan Mall, setiap pemilik kendaraan yang akan parkir di parkiran Grand Tarakan Mall di pintu masuk akan mengambil karcis parkir dari petugas loket dan pada saat keluar karcis parkir tersebut akan diperiksa oleh petugas loket di pintu keluar parkir sekaligus membayar ongkos parkir sesuai dengan tarif yang sudah ditentukan.

Pengelola parkir di Gusher Plasa, setiap orang yang akan parkir di parkiran Ghuser Plasa tidak menerima karcis parkir di pintu masuk dan pada saat keluar akan diberikan karcis parkir oleh petugas loket di pintu keluar dan membayar ongkos parkir sesuai dengan tarif. Hal ini mirip dengan parkir yang ada di THM Plasa dan juga parkir-parkir pinggir jalan yaitu pemilik kendaraan tidak diberikan karcis parkir saat memarkir kendaraannya justru diberikan karcis parkir saat selesai parkir dan akan menjalankan kendaraannya untuk meninggalkan parkiran.

Hal ini akan menimbulkan pertanyaan terkait asas konsensualisme antara pengguna jasa parkir dengan pihak pengelola parkir apakah saat pemilik kendaraan memarkir kendaraannya dianggap bahwa telah terjadi kesepakatan untuk perjanjian parkir atau pada saat karcis dan ongkos dibayarkan. Jika dianggap kesepakatan perjanjian terjadi pada saat kendaraan diparkir maka pertanyaan selanjutnya apa bukti yang dimiliki oleh konsumen terhadap kendaraan yang diparkir jika tidak diberikan karcis parkir. Jika dianggap kesepakatan terjadi saat ongkos dibayar dan karcis diberikan pertanyaannya siapa yang bertanggungjawab terhadap kendaraan selama berada di lokasi parkir.

Dapat dilihat bahwa penyelengaraan parkir yang seperti itu sangat merugikan konsumen, sebab kendaraan yang keluar/meninggalkan lokasi parkir tidak diperiksa karcis parkirnya, sedangkan jika terdapat kendaraan hilang di lokasi parkir maka pemilik kendaraan tidak mempunyai karcis yang membuktikan bahwa dia merupakan konsumen pengguna jasa parkir. Sangat terlihat bahwa pihak pengelola parkir hanya ingin menarik ongkos parkir dengan sama sekali tidak memberikan perlindungan bagi pemilik kendaraan bahkan sekedar untuk memeriksa karcis parkir.

Lalu bagaimana pertanggungjawaban pengelola jika ada kendaraan yang hilang di lokasi parkir, 
pihak pengelola tetap harus bertanggungjawab jika ada kendaraan yang hilang dari lokasi parkiran, yaitu berdasarkan wanprestasi jika dianggap terpenuhi asas konsensualismenya pada saat kendaraan di parkir. Sedangkan jika selama kendaraan tersebut diparkiran dianggap belum terjadi kesepakatan maka tanggung jawab tersebut dapat muncul dari Perbuatan Melanggar Hukum.

\section{PERUMUSAN MASALAH}

Dari uraian latar belakang di atas maka penulis merumuskan masalah sebagai berikut: Pertama, Bentuk perlindungan hukum bagi konsumen dalam perjanjian parkir; Kedua, Pertanggungjawaban pengelola parkir terhadap konsumen dalam perjanjian parkir; Ketiga, Implementasi perlindungan konsumen parkir di Kota Tarakan.

\section{METODE PENELITIAN}

Penelitian ini merupakan penelitian hukum normatif, yang merupakan suatu proses untuk menemukan aturan hukum, prinsip-prinsip hukum, maupun doktrin-doktrin hukum guna menjawab isu hukum yang dihadapi. ${ }^{4}$ Masih menurut Peter Mahmud Marzuki penelitian hukum dilakukan untuk menghasilkan argumentasi, teori atau konsep baru sebagai preskripsi dalam menyelesaikan masalah yang dihadapi.

Pendekatan yang digunakan dalam penelitian ini terdiri dari, pendekatan undang-undang (statute approach), pendekatan konseptual (conceptual approach), dan pendekatan historis atau sejarah (historical approach). Untuk memecahkan isu hukum dan sekaligus memberikan preskripsi mengenai apa yang seyogyanya diperlukan sumbersumber penelitian yang dapat dibedakan sumber penelitian yang berupa bahan hukum primer dan bahan hukum sekunder.

\section{PEMBAHASAN}

\section{Perlindungan Hukum Bagi Konsumen dalam Perjanjian Parkir}

Untuk mengetahui bentuk perlindungan hukum terhadap konsumen jasa parkir maka yang pertama hendak diketahui ialah hubungan hukum antara konsumen (pengguna jasa parkir) dengan pihak pengelola tempat parkir guna mengetahui hak dan

${ }^{4}$ Peter Mahmud Marzuki, Penelitian Hukum, Cetakan Kelima, Kecana, Jakarta, 2009, h. 35. kewajiban. Hak dan kewajiban hukum antara satu pihak terhadap pihak lain, dapat muncul karena dari adanya hubungan hukum dua belah pihak yang disebut perikatan. Berdasarkan pada Pasal 1233 KUHPerdata menegaskan bahwa Perikatan, lahir karena suatu persetujuan atau karena undangundang. Selanjutnya pada Pasal 1313 KUHPerdata menegaskan bahwa suatu persetujuan ialah suatu perbuatan yang satu orang atau lebih mengikatkan diri terhadap satu orang lain atau lebih.

Sedangkan perikatan yang timbul karena hukum (undang-undang), timbul karena perbuatan baik itu perbutan yang sesuai dengan hukum maupun perbuatan yang melanggar hukum. Pada Pasal 1352 KUHPerdata menegaskan bahwa perikatan yang lahir karena undang-undang, timbul dari undangundang sebagai undang-undang atau dari undangundang sebagai akibat perbuatan orang. Pasal 1353 KUHPerdata, perikatan yang lahir dari undangundang sebagai akibat perbuatan orang, muncul dari suatu perbuatan yang sah atau dari perbuatan yang melanggar hukum.

Dengan demikian dapat dikatan bahwa perikatan, lahir karena suatu perjanjian, atau karena undangundang. Lahir karena perjanjian, apabila adanya perikatan itu akibat kehendak para pihak itu sendiri, serta lahir karena undang-undang, apabila adanya perikatan itu akibat berlakunya aturan tertentu, atau perbuatan seseorang (baik yang sah, maupun yang melawan hukum).

Terkait masalah jasa parkir dapat dilihat bahwa jasa parkir merupakan suatu perikatan yang bisa timbul karena perjanjian atau perikatan yang timbul karena undang-undang, jika dilihat sebagai suatu perikatan yang timbul karena perjanjian maka termasuk perjanjian apakah perjanjian jasa parkir, terhadap persoalan ini terdapat dua pendapat yaitu: a. yang menyatakan bahwa perjanjian jasa parkir merupakan perjanjian penitipan barang; b. pendapat yang lain menyatakan bahwa perjanjian jasa parkir merupakan perjanjian sewa tempat, pengguna jasa parkir hanya menyewa tempat untuk memarkir kendaraannya sedangkan pihak pengelola parkir hanya menyediakan lahan atau tempat untuk parkir dengan demikian hubungan hukum yang terjadi ialah perjanjian sewa-menyewa, untuk menunjukkan bahwa hubungan hukum perparkiran ini merupakan hubungan sewa menyewa. 
Perjanjian penitipan barang dalam KUHPerdata diatur mulai dari Pasal 1694 sampai dengan Pasal 1729. Pasal 1694 menegaskan bahwa, Penitipan adalah terjadi apabila seorang menerima sesuatu barang dari orang lain, dengan syarat bahwa ia akan menyimpannya dan mengembalikannya dalam ujud asalnya. Pasal 1696 ayat (1) menegaskan bahwa, Penitipan barang sejatinya dianggap telah dibuat dengan cuma-cuma jika tidak diperjanjikan dengan sebaliknya. Pasal 1706 KUHPerdata menegaskan bahwa, Penerima titipan wajib memelihara barang titipan itu dengan sebaik-baiknya seperti memelihara barang-barang kepunyaan sendiri.

Pasal 1707 Ketentuan dalam pasal di atas ini wajib diterapkan secara lebih teliti, antara lain: a. jika penerima titipan itu yang mula-mula menawarkan diri untuk menyimpan barang itu; b. jika ia meminta dijanjikan suatu upah untuk penitipan itu; c. jika penitipan itu terjadi terutama untuk kepentingan penerima titipan; d. jika diperjanjikan dengan tegas, bahwa penerima titipan bertanggungjawab atau semua kelalaian dalam menyimpan barang titipan itu.

Dalam perjanjian penitipan barang tanggung jawab pengelola parkir terhadap konsumen parkir adalah memelihara barang titipan itu dengan sebaik-baiknya seperti memelihara barang-barang kepunyaan sendiri serta mengembalikan kendaraan dalam keadaan semula, ketentuan tersebut bahkan harus lebih teliti lagi jika penerima titipan itu yang mula-mula menawarkan diri untuk menyimpan barang itu dan jika ia meminta dijanjikan suatu upah untuk penitipan itu. Dengan kata lain apabila terjadi kerusakan dan bahkan kehilangan kendaraan di areal parkir merupakan tanggung jawab pengelola parkir.

Sedangkan obyek sewa menyewa diatur dalam KUHPerdata Pasal 1548 sampai dengan Pasal 1600, pada hubungan sewa menyewa, pengelola berkewajiban menyerahkan barang yang disewakan kepada penyewa. Selain itu, pengelola juga dapat memelihara barang yang disewakan sedemikian rupa hingga dapat dipakai untuk keperluan yang dimaksudkan serta memberikan kepada penyewa kenikmatan tenteram atas barang yang disewakan selama berlangsungnya waktu sewa. Pasal 1548 KUHPerdata menegaskan bahwa sewa menyewa ialah suatu perjanjian, dengan mana pihak yang satu mengikatkan dirinya untuk memberikan kepada pihak yang lainnya kenikmatan suatu barang, selama suatu waktu tertentu dan dengan pembayaran sesuatu harga, yang oleh pihak tersebut belakangan itu disanggupi pembayarannya.

Dapat disimpulkan dari pasal tersebut bahwa kewajiban dari pengelola itu adalah menyerahkan barang sewaan pada penyewa, memelihara barang sewaan dan untuk memberikan kenyamanan dalam penggunaan barang sewaan bagi penyewa selama masa sewa. Dikaitkan dengan perjanjian jasa parkir maka jika perjanjiannya dianggap sebagai perjanjian sewa menyewa maka terdapat beberapa unsur-unsur tertentu terkait perjanjian sewa menyewa yang diatur di dalam KUHPerdata yang tidak dapat terpenuhi secara dalam perjanjian parkir sebab si pemilik kendaraan yang menyewa lahan parkir tidak serta merta menguasai lahan yang disewa selama jangka waktu sewa, dalam arti setelah memarkirkan kendaraan si penyewa langsung meninggalkan lahan parkir sehingga tidak dapat menguasai atau memelihara lahan parkir dan konstruksi sewa menyewa ini adalah sewa menyewa tidak murni sehingga apabila terjadi kehilangan atau kerugian atas kendaraan di lahan yang disewa, maka penyewa masih mempunyai hak untuk menuntut ganti rugi kepada pihak yang menyewakan lahan karena walaupun lahan parkir telah disewakan kepada konsumen, namun penguasaan lahan parkir tetap pada pihak yang menyewakan (pengelola parkir).

Sedangkan sewa menyewa rumah dan tanah seperti yang terdapat di dalam KUHPerdata dimana si penyewa rumah memiliki kekuasaan penuh terhadap rumah yang dikuasainya selama jangka waktu sewa. Dengan demikian sudah selayaknya pengelola tetap mempunyai tanggung jawab terhadap kendaraan yang diparkir di lokasi parkir, sedangkan jika terjadi kehilangan atau kerusakan di dalam rumah selama jangka waktu sewa tidak dapat dimintai tanggung jawab kepada pemilik. ${ }^{5}$

Terkait perjanjian jasa parkir sering ditemui klausula baku yang bersifat eksonerasi yakni Keberadaan klausula eksonerasi dalam perjanjian didasarkan pada asas kebebasan berkontrak dalam Pasal 1388 ayat (1) KUHPerdata, dan secara terbatas masih dibolehkan pada Pasal 1493 dan Pasal 1494

\footnotetext{
${ }^{5}$ Berdasarkan putusan Mahkamah Agung Nomor 2078 K/ Pdt/2009 Perkara PT Securindo Packatama Indonesia vs Sumito Y. Viansyah (kasus kehilangan sepada motor di tempat parkir). Mahkamah Agung menyatakan bahwa hubungan hukum antara pengguna jasa parkir parkir dengan pengelola tempat parkir merupakan perjanjian penitipan.
} 
yang berbunyi sebagai berikut: Pada Pasal 1493 menegaskan bahwa, kedua belah pihak, dengan persetujuan-persetujuan istimewa boleh memperluas atau mengurangi kewajiban yang ditetapkan oleh undang-undang ini dan bahkan mereka boleh mengadakan persetujuan bahwa penjual tidak wajib menanggung sesuatu apa pun; Pada Pasal 1494 menegaskan bahwa, meskipun telah diperjanjikan bahwa penjual tidak akan menanggung sesuatu apa pun, ia tetap bertanggungjawab atas akibat dari suatu perbuatan yang dilakukannya, segala persetujuan yang bertentangan dengan ini adalah batal.

Dengan demikian pada hakekatnya klausula eksonerasi dalam perjanjian tidak lain adalah adanya pembagian beban resiko yang layak, namun dalam praktik makna klausula eksonerasi disalahgunakan oleh mereka yang memiliki keunggulan ekonomi dengan maksud untuk membebaskan diri dari beban tanggung jawab yang berlebihan tetapi juga sampai pada pengalihan tanggung jawab. Seperti misalnya menghilangkan kewajiban ganti rugi atas terjadinya kehilangan untuk perjanjian jasa penitipan.

Pada umumnya di dalam karcis parkir terdapat perjanjian standar yang memuat klausula eksonerasi (kadang kala pencantuman klausula eksonerasi tersebut dibuat dalam bentuk pengumuman pada plang yang terpasang di dekat loket karcis parkir, depan pintu masuk parkir dan di lokasi tempat parkir), yaitu seperti berikut ini: Bahwa kehilangan mobil atau barang berharga bukan tanggung jawab pihak pengelola parkir sehingga apabila terjadi peristiwa tersebut maka bukan menjadi tanggung jawab pihak pengelola parkir, dan Atas hilangnya kendaraan dan atau barang-barang yang berada di dalam kendaraan atau rusaknya kendaraan selama berada di petak parkir, merupakan tanggung jawab pemakai tempat parkir.

Berdasarkan peraturan perundang-undangan Nomor 8 Tahun 1999 tentang Perlindungan Konsumen (selanjutnya disebut UU Perlindungan Konsumen), terdapat klausul baku bersifat eksonerasi yang menghilangkan kewajiban ganti rugi atas terjadinya kehilangan bertentangan dan tidak sejalan dengan undang-undang tersebut. Pasal 18 ayat (1) huruf (a) UU Perlindungan Konsumen menegaskan bahwa pelaku usaha dalam menawarkan barang dan/atau jasa yang ditujukan untuk diperdagangkan dilarang membuat atau mencantumkan klausula baku pada setiap dokumen dan/atau perjanjian jika menyatakan pengalihan tanggung jawab kepada pelaku usaha.

Pada Pasal 18 ayat (3) menegaskan bahwa setiap klausula baku yang telah ditetapkan oleh pelaku usaha pada dokumen atau perjanjian yang memenuhi ketentuan sebagaimana dimaksud pada ayat (1) dan ayat (2) dinyatakan batal demi hukum. Dengan demikian klausula baku yang memuat klausula eksonerasi didalamnya dan berdasarkan Pasal 18 ayat (3) UU Perlindungan Konsumen dinyatakan batal demi hukum. Dengan demikian dapat dikatakan bahwa UU Perlindungan Konsumen menjadi lex specialist dari pengaturan umum yang ada pada KUHPerdata khususnya pada Pasal 1493 dan Pasal 1494.

Klausul baku dalam perjanjian boleh saja dibuat akan tetapi tidak boleh mengalihkan, membatasi atau menghindari tanggung jawab. Tidak boleh mengalihkan beban kepada konsumen, ada batasanbatasan klausul yang boleh dimuat dalam perjanjian.

\section{Pertanggungjawaban Pengelola Parkir dalam Perjanjian Parkir}

Pada Pasal 19 UU Perlindungan Konsumen menegaskan bahwa: Pelaku usaha bertanggungjawab memberikan ganti rugi atas kerusakan, pencemaran, dan atau kerugian konsumen akibat mengkonsumsi barang dan atau jasa yang dihasilkan atau diperdagangkan; dan Ganti rugi dapat berupa pengembalian uang atau penggantian barang dan/ atau jasa yang sejenis atau setara nilainya, atau perawatan kesehatan dan/atau pemberian santunan dan dilaksanakan dalam tenggang waktu 7 (tujuh) hari setelah tanggal transaksi; Pemberian ganti rugi tidak menghapuskan kemungkinan adanya tuntutan pidana berdasarkan pembuktian lebih lanjut mengenai adanya unsur kesalahan; dan pemberian ganti rugi tidak berlaku apabila pelaku usaha dapat membuktikan bahwa kesalahan tersebut merupakan kesalahan konsumen.

Pada Pasal 23 UU Perlindungan Konsumen menegaskan bahwa, pada pelaku usaha yang menolak dan atau tidak memberi tanggapan dan atau tidak memenuhi ganti rugi atas tuntutan konsumen sebagaimana dimaksud dalam Pasal 19 ayat (1) sampai dengan ayat (4) UU Perlindungan Konsumen, dapat digugat melalui Badan Penyelesaian Sengketa Konsumen atau mengajukan ke badan peradilan di tempat kedudukan konsumen. 
Jika dikaitkan dengan perjanjian jasa parkir, maka apakah pengelola parkir harus bertanggungjawab memberikan ganti rugi atas hilangnya kendaraan yang di parkir ditempatnya, pengelola parkir tidak dapat merujuk pada klausula eksonerasi dalam perjanjian parkir, yaitu bahwa dirinya tidak bertanggungjawab atas terjadinya kerusakan atau kehilangan kendaraan yang di parkir ditempatnya. Pengelola tempat parkir tidak boleh melepaskan tanggung jawab begitu saja.

Pengelola parkir wajib menyesuaikan klausula baku yang bertentangan dengan UU Perlindungan Konsumen. Bahkan untuk pelaku usaha dapat dikenakan sanksi pidana dalam hal pelaku usaha tetap melanggar ketentuan sebagaimana dimaksud dalam Pasal 18 UU Perlindungan Konsumen tersebut akan diberikan sanksi, baik sanksi pidana penjara atau pidana denda sebagaimana diatur dalam Pasal 62 ayat (1) UU Perlindungan Konsumen yang menegaskan bahwa, pelaku usaha yang melanggar ketentuan sebagaimana dimaksud dalam Pasal 8, Pasal 9, Pasal 10, Pasal 13 ayat (2), Pasal 15, Pasal 17 ayat (1) huruf a, huruf $b$, huruf $c$, huruf e, ayat (2) dan Pasal 18 dapat dipidana dengan pidana penjara paling lama 5 (lima) tahun atau pidana denda paling banyak Rp 2.000.000.000,00 (dua milyar rupiah).

Terdapat beberapa definisi yang perlu diberikan terhadap perbuatan melawan hukum adalah sebagai berikut: ${ }^{6}$ a. Tidak memenuhi sesuatu yang menjadi kewajibannya selain dari kewajiban kontraktual atau kewajiban quasi kontraktual yang menerbitkan hak untuk meminta ganti rugi; b. Suatu perbuatan atau tidak berbuat yang mengakibatkan timbulnya kerugian bagi orang lain tanpa sebelumnya ada suatu hubungan hukum, dimana perbuatan atau tidak berbuat tersebut baik merupakan suatu perbuatan biasa maupun bisa juga merupakan suatu kecelakaan; c. Tidak memenuhi suatu kewajiban yang dibebankan oleh hukum, kewajiban mana ditujukan terhadap setiap orang pada umumnya dan dengan tidak memenuhi kewajibannya tersebut dapat dimintakan suatu ganti rugi; d. Suatu kesalahan perdata (civil wrong) terhadap mana suatu ganti kerugian dapat dituntut yang bukan merupakan wanprestasi terhadap kontrak, atau wanprestasi terhadap kewajiban trust, atau pun wanprestasi terhadap kewajiban equity lainnya; e. Suatu kerugian yang tidak disebabkan oleh wanprestasi terhadap kontrak, atau lebih tepatnya, merupakan suatu perbuatan yang merugikan hak-hak orang lain yang diciptakan oleh hukum yang tidak terbit dari hubungan kontraktual; f. Sesuatu perbuatan atau tidak berbuat sesuatu yang secara bertentangan dengan hukum melanggar hak orang lain yang diciptakan oleh hukum, dan karenanya suatu ganti rugi dapat dituntut oleh pihak yang dirugikan; g. Perbuatan melawan hukum bukan suatu kontrak.

Dari pelaksanaan jasa parkir yang sudah diamati di atas jelas bahwa hampir semua jasa parkir di Kota Tarakan tidak memberikan perlindungan konsumen pada konsumen pengguna jasa parkir, pengecualiannya pada parkiran Bandara Juwata Tarakan dan Grand Tarakan Mall.

Berdasarkan hukum perdata, perjanjian jasa parkir dapat dilihat sebagai perjanjian sewamenyewa dan juga dapat dilihat sebagai perjanjian penitipan barang. Pada hubungan sewa menyewa, penyewa berkewajiban menyerahkan barang yang disewakan kepada penyewa. Pengertian Sewa menyewa ialah suatu perjanjian, dengan mana pihak yang satu mengikatkan dirinya untuk memberikan kepada pihak yang lainnya kenikmatan suatu barang, selama suatu waktu tertentu dan dengan pembayaran sesuatu harga, yang oleh pihak tersebut belakangan itu disanggupi pembayarannya. Dapat disimpulkan bahwa kewajiban dari pengelola itu adalah menyerahkan barang sewaan pada penyewa, memelihara barang sewaan dan untuk memberikan kenyamanan dalam penggunaan barang sewaan bagi penyewa selama masa sewa. Jika perjanjian parkir dianggap sebagai perjanjian sewa menyewa maka si pemilik kendaraan yang menyewa lahan parkir tidak serta merta menguasai lahan yang disewa selama jangka waktu sewa, dalam arti setelah memarkirkan kendaraan si penyewa langsung meninggalkan lahan parkir sehingga tidak dapat menguasai atau memelihara lahan parkir dan konstruksi sewa menyewa ini adalah sewa menyewa tidak murni sehingga apabila terjadi kehilangan atau kerugian atas kendaraan di lahan yang disewa, maka penyewa masih mempunyai hak untuk menuntut ganti rugi kepada pihak yang menyewakan lahan karena walaupun lahan parkir telah disewakan kepada konsumen, namun penguasaan lahan parkir tetap pada pihak yang menyewakan (pengelola parkir).

${ }^{6}$ W. Page Keaton, et.al, Prosser and Keeton on Torts, $5^{\text {th }}$ edition, West Group, 1984, h. 1-2. 


\section{PENUTUP}

\section{Kesimpulan}

Pada perjanjian penitipan barang terjadi apabila seorang menerima sesuatu barang dari orang lain, dengan syarat bahwa ia akan menyimpannya dan mengembalikannya dalam ujud asalnya. Penerima titipan wajib memelihara barang titipan itu dengan sebaik-baiknya seperti memelihara barang-barang kepunyaan sendiri. Dalam perjanjian penitipan barang tanggung jawab pengelola parkir terhadap konsumen parkir adalah memelihara barang titipan itu dengan sebaik-baiknya seperti memelihara barangbarang kepunyaan sendiri serta mengembalikan kendaraan dalam keadaan semula, ketentuan tersebut bahkan harus lebih teliti lagi jika penerima titipan itu yang mula-mula menawarkan diri untuk menyimpan barang itu dan jika ia meminta dijanjikan suatu upah untuk penitipan itu. Dengan kata lain apabila terjadi kerusakan dan bahkan kehilangan kendaraan di areal parkir merupakan tanggung jawab pengelola parkir. Mahkamah Agung melihat perjanjian jasa parkir sebagai perjanjian penitipan barang.

Menurut UU Perlindungan Konsumen, klausul baku bersifat eksonerasi yang menghilangkan kewajiban ganti rugi atas terjadinya kehilangan bertentangan dan tidak sejalan dengan undangundang tersebut. Dalam hukum perdata klausul baku dalam perjanjian boleh saja dibuat akan tetapi tidak boleh mengalihkan, membatasi atau menghindari tanggung jawab. Tidak boleh mengalihkan beban kepada konsumen, ada batasan-batasan klausul yang boleh dimuat dalam perjanjian.

Dari pelaksanaan jasa parkir yang sudah diamati di atas jelas bahwa hampir semua jasa parkir di Kota Tarakan tidak memberikan perlindungan konsumen pada konsumen pengguna jasa parkir, pengecualiannya pada di wilayah parkiran Bandara Juawata Tarakan serta Grand Tarakan Mall. Pengelola parkir di Kota Tarakan hampir semunya tidak memberikan karcis parkir kepada konsumen. Hal ini akan menimbulkan pertanyaan terkait asas konsensualisme antara pengguna jasa parkir dengan pihak pengelola parkir apakah saat pemilik kendaraan memarkir kendaraannya dianggap bahwa telah terjadi kesepakatan untuk perjanjian parkir atau pada saat karcis dan ongkos dibayarkan. Jika dianggap kesepakatan perjanjian terjadi pada saat kendaraan di parkir maka pertanyaan selanjutnya apa bukti yang dimiliki oleh konsumen terhadap kendaraan yang di parkir jika tidak diberikan karcis parkir. Jika dianggap kesepakatan terjadi saat ongkos dibayar dan karcis diberikan pertanyaannya siapa yang bertanggungjawab terhadap kendaraan selama berada di lokasi parkir.

Dapat dilihat bahwa penyelengaraan parkir yang seperti itu sangat merugikan konsumen, sebab kendaraan yang keluar atau meninggalkan lokasi parkir tidak diperiksa karcis parkirnya, sedangkan jika kendaraan hilang di lokasi parkir maka pemilik kendaraan tidak mempunyai karcis yang membuktikan bahwa dia merupakan konsumen pengguna jasa parkir. Sangat terlihat bahwa pihak pengelola parkir hanya ingin menarik ongkos parkir dengan sama sekali tidak memberikan perlindungan bagi pemilik kendaraan bahkan sekedar untuk memeriksa karcis parkir. Namun pihak pengelola tetap harus bertanggungjawab jika ada kendaraan yang hilang dari lokasi parkiran, yaitu berdasarkan wan prestasi jika dianggap terpenuhi asas konsensualismenya pada saat kendaraan di parkir. Sedangkan jika selama kendaraan tersebut diparkiran dianggap belum terjadi kesepakatan maka tanggung jawab tersebut dapat muncul dari Perbuatan Melanggar Hukum.

\section{Rekomendasi}

Pengelola parkir harus mampu bertanggungjawab memberikan ganti rugi atas hilangnya kendaraan yang diparkir di tempatnya, pengelola parkir tidak dapat merujuk pada klausula eksonerasi dalam perjanjian parkir, yaitu bahwa dirinya tidak bertanggungjawab atas terjadinya kerusakan atau kehilangan kendaraan yang di parkir ditempatnya. Pengelola tempat parkir tidak boleh melepaskan tanggung jawab begitu saja. Bahkan bagi pelaku usaha dapat dikenakan sanksi pidana dalam hal pelaku usaha tetap melanggar ketentuan (membuat klausula baku yang bersifat eksonerasi) sebagaimana dimaksud dalam Pasal 18 UU Perlindungan Konsumen tersebut akan diberikan sanksi, baik sanksi pidana penjara atau pidana.

\section{DAFTAR PUSTAKA}

\section{Peraturan Perundang-undangan:}

Undang-Undang Nomor 22 Tahun 2009 tentang Lalu Lintas dan Angkutan Jalan, Lembaran Negara Nomor 96 Tahun 2009, Tambahan Lembaran Negara Nomor 5025.

Undang-Undang Nomor 8 Tahun 1999 tentang 
Perlindungan Konsumen, Lembaran Negara Nomor 42 Tahun 1999, Tambahan Lembaran Negara Nomor 3821.

Putusan Mahkamah Agung Nomor 2078K/Pdt/2009

Perkara PT. Securindo Packatama Indonesia vs Sumito Y. Viansyah.

\section{Buku:}

Keaton, W. Page. 1984. Prosses and keeton on Torts. $5^{\text {th }}$ edition. West Group.

Marzuki, Peter Mahmud. 2009. Penelitian Hukum. Cetakan Kelima. Jakarta: Kencana.

Satrio J. 2008. Hukum Perjanjian. Cetakan ke-22. Jakarta: Intermasa.
Soebekti, R. dan R. Tjitrosudibio. 1976. Kitab Undang-Undang Hukum Perdata (Burgerlijk Wetboek). Terjemahan Cet. B. Jakarta: Pradnya Paramita.

\section{Website dan Surat Kabar:}

Badan Pusat Statistik. Perkembangan Jumlah Kendaraan Bermotor Menurut Jenis tahun 1987-2011. http://www.bps.go.id/ tab_sub/view.php?tabel=1\&daftar=1\&id subyek=17\&notab=12 (Akses Jum'at 08 Maret 2013 jam 11:33).

Kaltara Raya. Radar Tarakan. 20 September 2013. 